\title{
Efficient transfer of embryonic stem cells into the cochlea via a non-invasive vestibular route
}

\author{
MARK PRAETORIUS ${ }^{3}$, IGNACIO VICARIO $^{2} \&$ THOMAS SCHIMMANG $^{1,2}$ \\ ${ }^{1}$ Instituto de Biología y Genética Molecular, Universidad de Valladolid y Consejo Superior de Investigaciones Cientificas, \\ Valladolid, Spain, ${ }^{2}$ Center for Molecular Neurobiology, University of Hamburg, Hamburg and ${ }^{3}$ Department of \\ Otolaryngology, University of Heidelberg Medical Center, Germany
}

\begin{abstract}
Conclusion. Cell transplantation into the utriculus provides an efficient and non-invasive route to introduce embryonic stem (ES) cells into the vestibular and cochlear portions of the inner ear. Objective. The transfer of stem cells into the inner ear for therapeutic purposes is an important approach to cure damage to the cochlea and vestibulum. A key issue is to provide an entry point for cell transplants into the inner ear that does not affect its physiologic functions. The aim of this study was to examine the feasibility of transferring ES cells into the inner ear via the utriculus. Materials and methods. ES cells were injected via utriculostomy into the mouse inner ear. The distribution of the injected cells was determined using a betagalactosidase marker gene expressed by the ES cells. Results. Injected ES cells were found within the perilymph of the scala tympani and vestibuli. Moreover, ES cells were detected close to the cochlear sensory epithelium and spiral limbus.
\end{abstract}

Keywords: Inner ear, utriculus, cell therapy

\section{Introduction}

Diseases of the inner ear such as presbycusis, tinnitus, sudden hearing loss or vertigo affect millions of people worldwide. To date, there are only symptomatic treatments of empiric pharmacology or technical devices for hearing loss. There is no specific cure and in the case of vertigo there is no cure at all. The advent of stem cells has raised some hope for these patients. With their potential to differentiate into virtually any cell type, it might be possible to replace sensory or neuronal cells within the inner ear, thereby restoring the inner ear function of hearing and balance $[1,2]$.

Next to the question as to whether stem cells of embryonic or adult origin will be able to fulfill the physiologic functions of endogenous inner ear cells, a key issue is to resolve how to transfer cells inside the inner ear. In this context transfer into the cochlea is especially difficult due to its complex and fragile structure composed of liquid-filled spaces surrounded by membranes and encased within the temporal bone [2]. Access routes to the cochlea have classically comprised drilling a hole into the cochlea via cochleostomy, providing access to the scala tympani or even directly to the scala media, thus providing a direct entry point for cells to reach the organ of Corti. Alternatively, cells may be transplanted without cochleostomy via a less invasive route by injecting them through the round window $[3,4]$. Another route with no damage to the membranes that seal the endolymphatic and perilymphatic spaces is provided by injection into the internal auditory meatus [5]. However, in all cases these manipulations are associated with localized surgical trauma to the cochlea and carry the risk of inflammation and sensorineural hearing loss $[2,6,7]$. Thus, an approach that avoids direct physical contact with the cochlea may provide a more safe and reliable route to transfer cells into the cochlea. We have recently defined a non-invasive route for gene transfer into the cochlea that uses the utriculus as an entry point into the inner ear [8]. Here, we have tested the feasibility of using this protocol to

Correspondence: Dr Thomas Schimmang, IBGM, C/Sanz y Forés s/n, 47003 Valladolid, Spain. Tel: +34 983184818. Fax: +34 983423588. E-mail: schimman@ibgm.uva.es 


\section{M. Praetorius et al.}

introduce embryonic stem (ES) cells into the cochlea. Our results demonstrate that ES cells introduced via the utriculus efficiently reach the cochlea and are found next to potential targets for cell therapy. This protocol may thus be further developed as a non-invasive route for ES cell-based therapies within the cochlea.

\section{Materials and methods}

Animals and anesthesia

All studies used adult C57BL/6 mice and were approved by the University of Homburg/Saar guidelines for animal care and housing. Anesthesia for surgery and hearing measurements was induced using a mixture of fentanyl $(0.05 \mathrm{mg} / \mathrm{kg}$; Janssen Cilag, Germany), midazolam (2 mg/kg; HoffmannLa-Roche, Germany), and medetomidine $(0.15 \mathrm{mg} /$ kg; SmithKline Beecham, Finland).

\section{Stem cell culture}

ES cells that carry a beta-galactosidase gene integrated at the ROSA26 locus [9] were cultured under routine conditions [10]. ES cells were maintained on $10 \mathrm{~mm}$ tissue culture dishes containing a mitomycin C-treated mouse embryonic fibroblast layer. ES cells were washed three times in PBS, $5 \mathrm{ml} 0.25 \%$ trypsin-EDTA were added, and cells were incubated at $37^{\circ} \mathrm{C}$ for $5 \mathrm{~min}$. Cells were then gently pipetted to obtain a single-cell suspension, centrifuged at $700 \mathrm{~g}$ for $5 \mathrm{~min}$, and finally resuspended in ES cell medium and distributed onto fresh culture dishes. ES cell medium consisted of DMEM with Glutamax-I, supplemented with $15 \%$ ES-tested FBS, $1 \%$ NEAA, $1 \%$ penicillin-streptomycin, $10 \mathrm{mM}$ Hepes, $0.1 \mathrm{mM}$ 2-mercaptoethanol, and $1000 \mathrm{U} / \mathrm{ml} \mathrm{LIF}$.

\section{Surgical procedure}

The procedure was carried out as described elsewhere [8]. Briefly, after induction of anesthesia, a dorsal post-auricular approach allowed exposure of the facial nerve, the posterior semicircular canal, and the bulla. A diamond drill was used to open the bulla. After identification of the stapes, the stapedial artery, and the round window niche (Figure 1), the bone covering the utriculus was determined just below the stapedial artery dorsal to the basal cochlear turn and round window membrane niche. Inferior to the stapedial artery just below the entry of the middle ear cavity, an utriculostomy was performed using a $0.5 \mathrm{~mm}$ diamond drill. Then $4 \mu \mathrm{l}$ of the suspended stem cells were slowly applied through the utriculostomy using a $10 \mu \mathrm{l}$ Hamilton syringe with a 28 gauge blunt needle $(n=5)$ followed

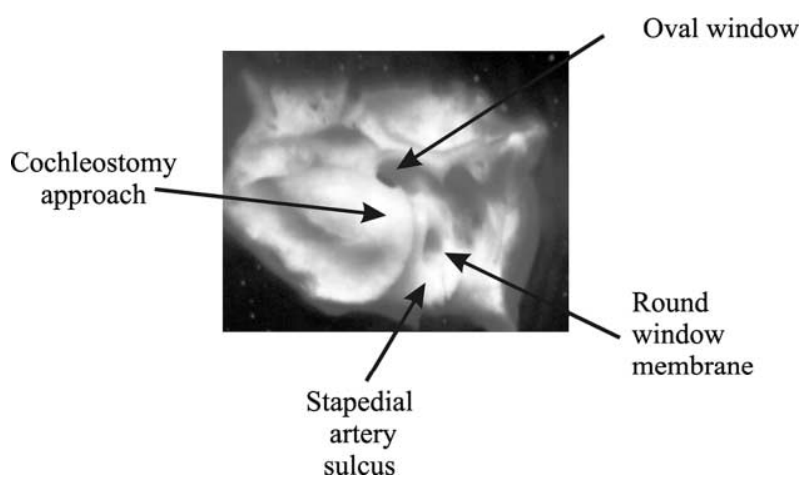

Figure 1. Isolated inner ear indicating the stapedial artery sulcus and the round window membrane. The oval window and the entry site for a cochleostomy are also indicated.

by a small patch of connective tissue that was subsequently placed onto the opening. Application of $4 \mu \mathrm{l}$ of $0.9 \% \mathrm{NaCl}$ solution and connective tissue at the utriculostomy in two mice served as controls.

\section{Immunohistochemistry and histology}

At 4 days after the application procedure, animals were euthanized by intracardiac perfusion with $2 \%$ PBS-buffered paraformaldehyde. The cochleae and brains were removed and post-fixed for $2 \mathrm{~h}$ in $2 \%$ paraformaldehyde, $125 \mathrm{mM}$ sucrose, and $100 \mathrm{mM}$ PBS ( $\mathrm{pH}=7.4)$ at $4{ }^{\circ} \mathrm{C}$. The cochleae were decalcified in Calex (Fisher Diagnostics, USA) for $2 \mathrm{~h}$ at room temperature. All samples were embedded in paraffin, sectioned in $6 \mu \mathrm{m}$ slices, deparaffinized, stained with hematoxylin and eosin (H\&E), sealed with vectastain and a coverslip, and evaluated microscopically. To detect the expression of the lac $Z$ gene expressed by the stem cell line, immunostaining with an antibody against beta-galactosidase (Sigma) and a secondary antibody labelled with rhodamine was performed.

\section{Results}

Transfer of ES cells into the inner ear via utriculostomy

Following the injection of ES cells via the utriculus (see Materials and methods) cochleae were examined for the distribution of ES cells in the cochlea after 4 days. Sections stained with H\&E revealed a high amount of injected ES cells within the scala tympani and vestibuli at all levels along the basalapical axis of the cochlea (Figure 2 and data not shown).

\section{Localization of ES cells within the cochlea}

To further identify and localize the injected ES cells within the cochlea we stained sections with an antibody directed against beta-galactosidase that 

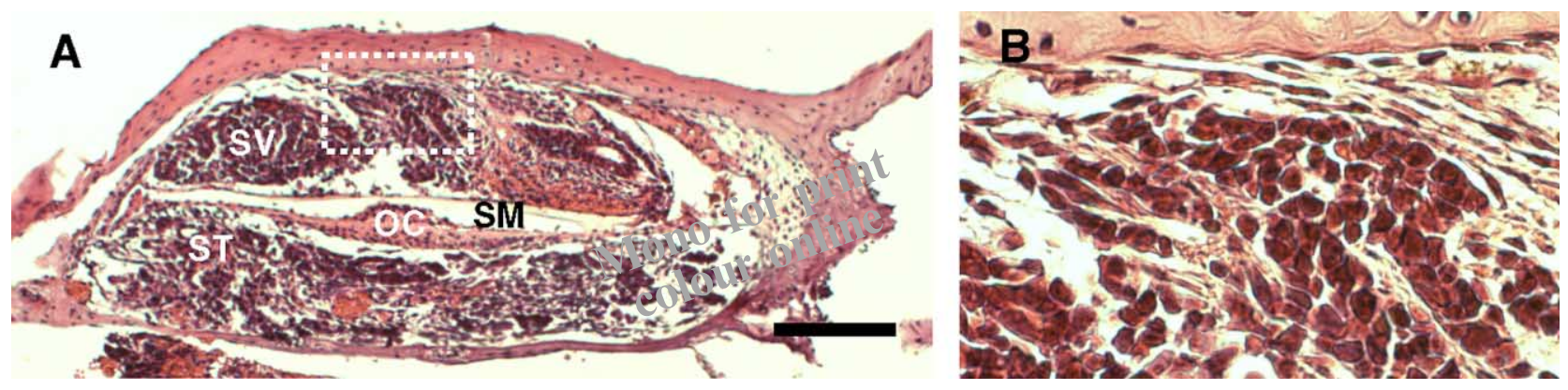

Figure 2. Presence of embryonic stem cells in the cochlea after cellular transfer into the utriculus. (A) Section through the apical part of the cochlea. Note the presence of embryonic stem cells in the scala vestibuli (SV) and scala tympani (ST), but not in the scala media (SM). (B) Magnification of the boxed area indicated in (A). OC, organ of Corti. Scale bar corresponds to $200 \mu \mathrm{m}$.

specifically detects ES cells since they carry a betagalactosidase gene integrated within their genome [9]. Inspection of sections under the immunofluorescence microscope revealed the presence of ES cells expressing beta-galactosidase (Figure 3). Aggregates or clumps of cells could be detected in the scala tympani underneath the organ of Corti (Figure 3A) and attached to the spiral limbus (Figure 3B).

\section{Discussion}

The introduction of stem cells into the cochlea to replace lost or damaged sensory cells or neurons is an attractive objective. However, several hurdles have to be overcome to guarantee a reliable and safe protocol for cell transfer to the target areas. Firstly, the introduction of the cells should be minimally invasive to the cochlear structures. Many protocols have relied on cochleostomy or injection through the round window membrane, which carries several risks for damage to the cochlea and consequently hearing loss $[2,6,7]$. The vestibular route is thus an attractive alternative that leaves the sensitive cochlear structures untouched. Our results demonstrate that injection of ES cells into the utriculus leads to an efficient transfer of ES cells to the scala tympani and scala vestibuli. Injected cells reach the scalae via the radial and longitudinal circulation of perilymph and apparently travel via the helicotrema from the scala vestibuli to the scala tympani. Importantly, injected ES cells are found close to the eventual targets of cellular therapy, e.g. the organ of Corti or the cochlear ganglion and its nerve fibers within the spiral limbus.

Alternative entry points for cell transfer in the vestibular system are the semicircular canals $[11,12]$. Comparative studies have confirmed that transfer of stem cells or viral vectors to the cochlea via canalostomy preserves cochlear function whereas cochleostomy leads to hearing loss [11,13]. Our recent studies have demonstrated that gene transfer into the utriculus did not affect auditory brainstem responses (ABRs) of the operated animals [8]. However, the high amount of ES cells present in
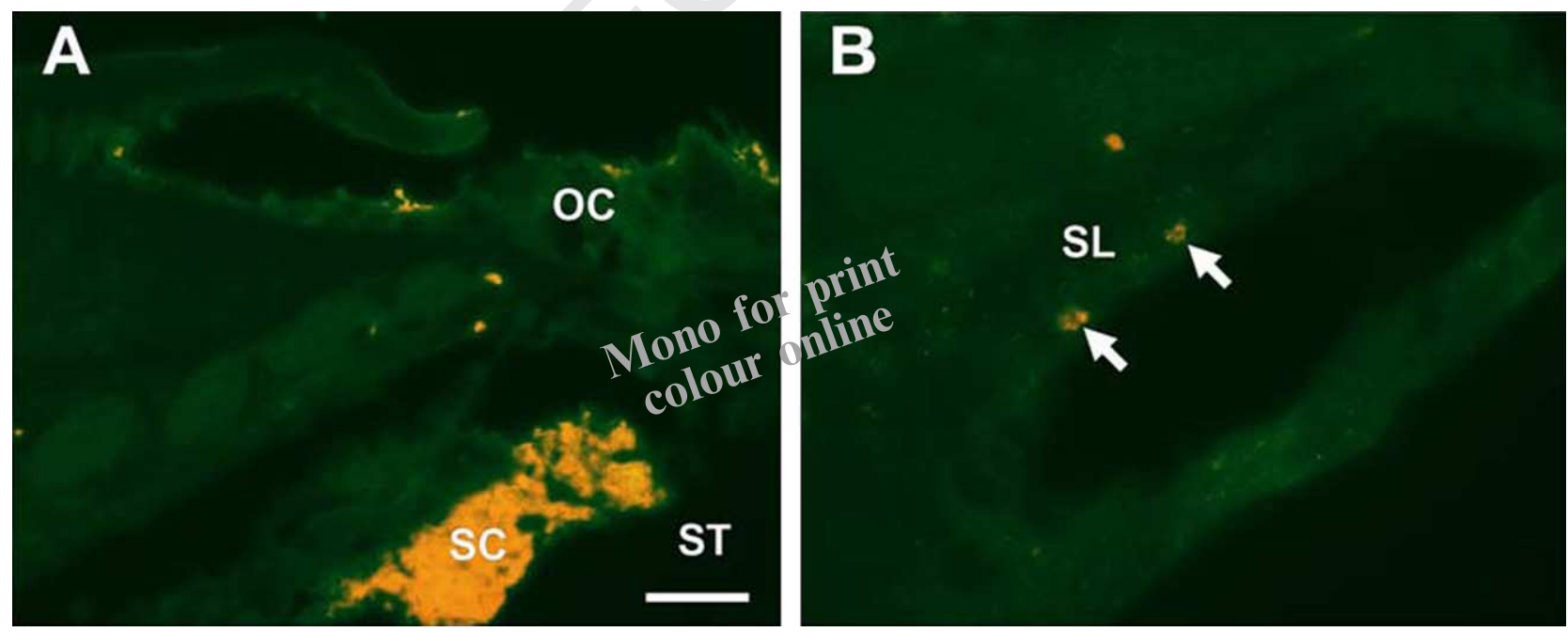

Figure 3. Detection of embryonic stem cells (SC) in the cochlea. Antibodies raised against beta-galactosidase detect SC in the scala tympani (ST) underneath the organ of Corti (OC) in (A). In (B) SC (marked by arrows) are found attached to the spiral limbus (SL). Scale bar corresponds to $50 \mu \mathrm{m}$ in (A) and $75 \mu \mathrm{m}$ in (B). 


\section{M. Praetorius et al.}

the scala tympani in the present study will affect the normal physiology of the cochlea. Therefore, the amount of injected ES cells will have to be reduced or their distribution throughout the cochlea improved. On the other hand, operated animals that received ES cells (this study) or viral vectors [8] by utriculostomy showed no behavioral abnormalities, indicating that no vestibular defects had been caused. Finally, we found no indications for an inflammatory response. Therefore, although the technique described here needs further refinement the utriculus appears to represent an attractive entry point for cell-based therapies.

An apparent drawback of the vestibular approach is that cells within the scala tympani or scala vestibuli would still have to reach their final destinations within the cochlear sensory epithelium or the cochlear ganglion. However, several studies have now provided evidence that stem cells are able to reach Rosenthal's canal and the scala media, most likely by their migration from the scala tympani through the caniculae perforantes of Schuhknecht $[3,5,14,15]$. Moreover, different types of injected stem cells, including ES cells, have been shown to express neuronal or hair cell markers and to integrate within the relevant target areas for cellular therapy [14,16-19]. Interestingly, stem cells within the perilymphatic space have also been shown to ameliorate hearing impairment observed 4 days after transient cochlear ischemia without transdifferentiation into cochlear cell types [20]. Continued research on the safe transfer of stem cells to the cochlea and stem cell differentiation within the inner ear may thus provide important insights for future stem cell-based therapies.

\section{Acknowledgements}

We thank Dieter Riethmacher for providing ES cells. Supported by the Instituto de Salud Carlos III (Red de Terapia Celular).

\section{References}

[1] Hu Z, Ulfendahl M. Cell replacement therapy in the inner ear. Stem Cells Dev 2006;15:449-59.

[2] Richardson RT, Noushi F, O'Leary S. Inner ear therapy for neural preservation. Audiol Neurootol 2006;11:343-56.

[3] Coleman B, Hardman J, Coco A, Epp S, de Silva M, Crook J, et al. Fate of embryonic stem cells transplanted into the deafened mammalian cochlea. Cell Transplant 2006; $15: 369-80$.
[4] Hildebrand MS, Dahl HH, Hardman J, Coleman B, Shepherd RK, de Silva MG. Survival of partially differentiated mouse embryonic stem cells in the scala media of the guinea pig cochlea. J Assoc Res Otolaryngol 2005;6:341-54.

[5] Sekiya T, Kojima K, Matsumoto M, Kim TS, Tamura T, Ito J. Cell transplantation to the auditory nerve and cochlear duct. Exp Neurol 2006;198:12-24.

[6] Carvalho GJ, Lalwani AK. The effect of cochleostomy and intracochlear infusion on auditory brain stem response threshold in the guinea pig. Am J Otol 1999;20:87-90.

[7] Stover T, Yagi M, Raphael Y. Cochlear gene transfer: round window versus cochleostomy inoculation. Hear Res 1999; 136:124-30.

[8] Praetorius M, Knipper M, Schick B, Tan J, Limberger A, Carnicero E, et al. A novel vestibular approach for gene transfer into the inner ear. Audiol Neurootol 2002;7:324-34.

[9] Brockschnieder D, Lappe-Siefke C, Goebbels S, Boesl MR, Nave KA, Riethmacher D. Cell depletion due to diphtheria toxin fragment A after Cre-mediated recombination. Mol Cell Biol 2004;24:7636-42.

[10] Riethmacher D, Lim F, Schimmang T. Efficient transfer of HSV-1 amplicon vectors into embryonic stem cells and their derivatives. Methods Mol Biol 2006;329:265-72.

[11] Iguchi F, Nakagawa T, Tateya I, Endo T, Kim TS, Dong Y, et al. Surgical techniques for cell transplantation into the mouse cochlea. Acta Otolaryngol Suppl 2004;551:43-7.

[12] Sakamoto T, Nakagawa T, Endo T, Kim TS, Iguchi F, Naito $\mathrm{Y}$, et al. Fates of mouse embryonic stem cells transplanted into the inner ears of adult mice and embryonic chickens. Acta Otolaryngol Suppl 2004;551:48-52.

[13] Kawamoto K, Oh SH, Kanzaki S, Brown N, Raphael Y. The functional and structural outcome of inner ear gene transfer via the vestibular and cochlear fluids in mice. Mol Ther 2001;4:575-85.

[14] Hu Z, Wei D, Johansson CB, Holmstrom N, Duan M, Frisen J, et al. Survival and neural differentiation of adult neural stem cells transplanted into the mature inner ear. Exp Cell Res 2005;302:40-7.

[15] Matsuoka AJ, Kondo T, Miyamoto RT, Hashino E. In vivo and in vitro characterization of bone marrow-derived stem cells in the cochlea. Laryngoscope 2006;116:1363-7.

[16] $\mathrm{Hu} Z$, Andang M, Ni D, Ulfendahl M. Neural cograft stimulates the survival and differentiation of embryonic stem cells in the adult mammalian auditory system. Brain Res 2005;1051:137-44.

[17] Iguchi F, Nakagawa T, Tateya I, Kim TS, Endo T, Taniguchi Z, et al. Trophic support of mouse inner ear by neural stem cell transplantation. Neuroreport 2003;14: $77-80$.

[18] Ito J, Kojima K, Kawaguchi S. Survival of neural stem cells in the cochlea. Acta Otolaryngol (Stockh) 2001;121: 140-2.

[19] Tamura T, Nakagawa T, Iguchi F, Tateya I, Endo T, Kim TS, et al. Transplantation of neural stem cells into the modiolus of mouse cochleae injured by cisplatin. Acta Otolaryngol Suppl 2004;551:65-8.

[20] Yoshida T, Hakuba N, Morizane I, Fujita K, Cao F, Zhu P, et al. Hematopoietic stem cells prevent hair cell death after transient cochlear ischemia through paracrine effects. Neuroscience 2007;145:923-30. 